\title{
Precautions When Providing Dental Care During Coronavirus Disease 2019 (COVID-19) Pandemic
}

Adrian H $\underline{\text { Shi}},{ }_{B D S, M D S}$, Weidi Guo, ${ }^{2}{ }_{B D S, M D S}$, Chai Kiat Chng, ${ }^{3}{ }_{B D S, M D S, F A M S}$, Boon Hui Chan, ${ }_{B D S, M D S}$

\begin{abstract}
Transmission of coronavirus disease 2019 (COVID-19) — caused by novel severe acute respiratory syndrome coronavirus 2 - through aerosolised saliva and respiratory droplets is possible when aerosol-generating dental procedures are performed. Consequently, dental practitioners are at increased risk of being infected when treating COVID-19 patients. A comprehensive review of the current literature on precautions when providing dental care during the COVID-19 pandemic is discussed and recommendations for dental practitioners are made. Dental practitioners should actively keep themselves abreast of the guidelines published by both national and international authorities and adhere strictly to them.
\end{abstract}

Ann Acad Med Singapore 2020;49:312-19

Keywords: Aerosol-generating procedures, Infection control, Infectious disease, Severe acute respiratory syndrome coronavirus, Transmission

\section{Introduction}

Coronavirus disease 2019 (COVID-19) is caused by novel severe acute respiratory syndrome coronavirus 2 (SARS-CoV-2) and was first reported to the World Health Organization (WHO) as pneumonia of unknown aetiology in the Chinese city of Wuhan on 31 December 2019. Since then, COVID-19 has spread across the globe and a pandemic was declared on 11 March 2020 by the WHO. ${ }^{1}$ COVID-19 is transmitted through respiratory droplets and contact routes. ${ }^{2}$ Respiratory droplets are defined by the WHO as $>5 \mu \mathrm{m}$ in diameter and can be either aerosols $(<50 \mu \mathrm{m})$ or spatters $(>50 \mu \mathrm{m}) .{ }^{3}$ Although airborne transmission by droplet nuclei $(<5 \mu \mathrm{m})$ has not been ruled out, it is unlikely to be the main route of transmission. ${ }^{4,5}$

Aerosol-generating procedures are routinely performed in dentistry. Since SARS-CoV-2 has been found in saliva, ${ }^{6}$ it is also possible that COVID-19 can be transmitted by aerosolised saliva. The risk of nosocomial transmission is considered high in a dental setting. The WHO has recommended droplet and contact precautions for healthcare workers who are caring for COVID-19 patients. ${ }^{7}$ This guideline included additional precautions for airborne transmission in clinical settings for aerosol-generating procedures.

\footnotetext{
${ }^{1}$ Department of Oral and Maxillofacial Surgery, National Dental Centre, Singapore

${ }^{2}$ Dental Branch, MMI, Singapore Armed Forces Headquarters Medical Corps, Singapore

${ }^{3}$ Office of the Director of Medical Services, Ministry of Health, Singapore

${ }^{4}$ Dental Service, KK Women's and Children's Hospital, Singapore

Address for Correspondence: Dr Chan Boon Hui, Dental Service, KK Women’s and Children's Hospital, 100 Bukit Timah Road, Singapore 229899.

Email: chan.boon.hui@kkh.com.sg
} 
Past experience in respiratory infection pandemics suggests that the dental profession can be overlooked when new infections emerge. ${ }^{8}$ Currently, there is also a lack of guidance on precautions when providing dental care during the COVID-19 pandemic. In this review, we examine the literature on the subject and recommend several precautionary measures that can be taken.

\section{Transmission Routes in Dentistry}

Contact transmission is one of the main modes of transmission in COVID- $19,{ }^{2}$ and it can occur through fomites in the immediate environment or through objects used by an infected person. ${ }^{9}$ Environmental contamination is shown to be possible even in infected patients who showed mild symptoms. ${ }^{9}$ SARS-CoV-2 can persist on surfaces from between a few hours to several days, depending on the surface type, temperature and humidity of the environment. ${ }^{4,10}$ A laboratory experiment that used droplet nuclei of SARS-CoV-2 $(<5 \mu \mathrm{m})$ had demonstrated that viable viruses could remain suspended in the air for up to 3 hours. ${ }^{11}$ On plastic and stainless steel surfaces, the virus can remain viable for up to 72 hours; on copper and cardboard surfaces, it becomes non-viable after 4 and 24 hours, respectively. ${ }^{11}$

Another established mode of transmission of COVID-19 is through expelled respiratory droplets $(>5 \mu \mathrm{m}),{ }^{2}$ and they are classified as either aerosols $(<50 \mu \mathrm{m})$ or spatters $(>50 \mu \mathrm{m}))^{3,12,13}$ Direct droplet transmission occurs after the mucosae or conjunctivae are exposed to respiratory droplets from an infected patient in close proximity. Since the SARS-CoV-2 virus measures approximately 50-200 nm, aerosols can contain large amounts of viruses. ${ }^{14}$ Aerosols can be suspended in the air for up to 30 minutes before they settle on surrounding surfaces or are inhaled into the respiratory tract. ${ }^{15}$ Smaller aerosol particles that measure 5-10 $\mu \mathrm{m}$ have the potential to penetrate deeper into the smaller lung passages and have the highest risk of transmission. . $^{2,16,16,17}$ When they are ejected from the oral cavity, splatter particles behave in a ballistic manner and follow an arcing trajectory that is similar to that of a bullet. These larger particles are only suspended in the air for a brief interval. ${ }^{16}$

Airborne transmission by droplet nuclei $(<5 \mu \mathrm{m})$ is a controversial issue since it has not been ruled out by current evidence. ${ }^{4}$ Droplet nuclei are either formed from the evaporation of larger droplets or are found in dust particles. They have the ability to remain suspended in the air for longer periods and can be transmitted over distances $>1 \mathrm{~m}^{2,3}$ Although it is theoretically possible to generate droplet nuclei from aerosol-generating procedures, results from an analysis of 75,465 COVID-19 cases in China did not reveal airborne transmission. ${ }^{5}$

Contact, aerosols, spatters and airborne transmissions are potential routes for infection in dentistry. ${ }^{16}$ Large amounts of aerosols are produced when rotary airdriven dental handpieces, ultrasonic scalers, air polishers, air abrasion units and water jets are used in the operatory. ${ }^{8,16}$ Consequently, dental practitioners are at increased risk of being infected during the COVID-19 pandemic. Additional measures must be put in place to mitigate the risks of infection in dental setting. ${ }^{18}$ The recommendations for dental practice during the COVID-19 pandemic are summarised in Table 1.

\section{Triage of Patients}

Dental practitioners should be aware of emerging infections and exercise heightened vigilance. They must keep abreast of disease features, transmission modes and incubation periods. The ability to identify a suspected COVID-19 patient is crucial ${ }^{19}$ and it can be performed at triage by using updated suspect case definition. During the COVID-19 pandemic, all patients should be screened for fever and current health status, as well as any travel history and/or close contact with confirmed COVID-19 cases. ${ }^{18}$ Patients who present with symptoms of acute respiratory illness should be isolated and referred to a medical physician for treatment.

The median incubation period of COVID-19 is 4 days and the quarantine and monitoring period is 14 days. ${ }^{20,21}$ Accordingly, for patients with a history of travel or close contact with COVID-19 cases, elective dental treatment should be deferred for at least 14 days from the date of return or last contact with COVID-19 cases. The WHO has recommended the use of a negative pressure room to treat suspected and positive COVID-19 patients who require emergency dental treatment. ${ }^{2}$ Such facilities are typically located in designated dental institutions that have been fitted with the appropriate infrastructure and equipment to manage these cases safely.

\section{Standard Precautions}

"Standard Precautions" were described by the Centers for Disease Control and Prevention (CDC) in the United States (US) in $1996^{22}$ and pertain to contact with blood, any type of body fluids, secretions and excretions (excluding sweat) regardless of whether they contain blood, non-intact skin and mucous membranes. A secondary level of precautions, "Transmission-Based Precautions", were designed to 
Table 1. Recommendations for Dental Practice During COVID-19 Pandemic

\begin{tabular}{|c|c|}
\hline Phase & Measures \\
\hline \multirow[t]{4}{*}{ Preprocedural } & Improve knowledge related to COVID-19 and be aware of disease features, transmission modes and incubation period. \\
\hline & $\begin{array}{l}\text { Triage of all patients using updated suspect case definition: } \\
\text { - Screen for fever, current health status, travel history and/or close contacts with confirmed COVID-19 cases. Defer treatment } \\
\text { for } 14 \text { days if needed. } \\
\text { - Refer patients with acute respiratory illness to a medical physician. }\end{array}$ \\
\hline & $\begin{array}{l}\text { Dental practice management measures: } \\
\text { - Implement a staff health surveillance system. } \\
\text { - Staff training for donning of PPE and fit-testing of particulate respirators. } \\
\text { - Redeploy staff who are at risk. } \\
\text { - Reduce number of people in clinic. } \\
\text { - Adhere to guidelines published by the authorities. }\end{array}$ \\
\hline & $\begin{array}{l}\text { Business continuity plans: } \\
\text { - Segregate staff into teams to minimise interactions. } \\
\text { - Establish a reliable form of communication with staff. }\end{array}$ \\
\hline \multirow[t]{7}{*}{ Procedural } & Observe Standard Precautions. \\
\hline & Practise proper hand hygiene. \\
\hline & Don appropriate PPE suitable for the procedure. \\
\hline & $\begin{array}{l}\text { Reduce contamination of operatory: } \\
\text { - } 0.23 \% \text { povidone-iodine mouthwash as a preprocedural mouthwash. } \\
\text { - Dry field technique. } \\
\text { - High-volume excavator. }\end{array}$ \\
\hline & Only perform urgent/emergency dental treatment. \\
\hline & $\begin{array}{l}\text { For dental treatment of suspect and confirmed COVID-19 cases, PPE should include gloves, long-sleeved gowns, eye protection } \\
\text { and fit-tested particulate respirators (N95 or equivalent, or higher level of protection). Treatment should be performed in a } \\
\text { negative pressure room and only essential staff are to be in the room. }\end{array}$ \\
\hline & Remove PPE and dispose it appropriately. \\
\hline \multirow[t]{3}{*}{ Postprocedural } & Equipment and surface decontamination with suitable disinfectants such as sodium hypochlorite and alcohol solutions. \\
\hline & Common areas and appliances are cleaned regularly. \\
\hline & Proper handling and disposal of biohazard waste. \\
\hline
\end{tabular}

COVID-19: Coronavirus disease 2019; PPE: Personal protective equipment

reduce the risk of transmission of pathogens through contact, droplets or airborne routes. The guidelines were revised in 2003 and expanded in 2007 to include isolation protocols that include more details on Transmission-Based Precautions. ${ }^{23,24}$ Examples of diseases that require Transmission-Based Precautions include influenza A (H1N1), severe acute respiratory syndrome coronavirus (SARS-CoV), tuberculosis and varicella zoster.

Standard Precautions were reported to be adequate in the prevention of transmission of infectious diseasessuch as influenza and rhinovirus - from dental aerosols. ${ }^{25}$ Samaranayake and Peiris reported that there were no cases of dental health workers who were infected during the SARS-CoV outbreak in $2003 .{ }^{19}$ Therefore, it is postulated that the practice of Standard Precautions by dental practitioners provides adequate protection against COVID-19 transmission and obviates the spread of COVID-19 in the dental setting. ${ }^{19,26}$ It is, however, important to note that all available guidelines have advised increased infection control measures in the treatment of COVID-19 patients. $^{10,27-29}$

\section{Personal Protective Equipment}

The use of personal protective equipment (PPE) is an important part of Standard Precautions that includes 
caps, protective eyewear, face masks, face shields, protective clothing and gloves. PPE protects the skin and mucous membranes of healthcare workers from exposure to or contact with infectious agents. Additionally, PPE protects patients from any pathogens that are found on health workers. Appropriate PPE should be donned in accordance to the modes of transmission of pathogens. ${ }^{22}$ During the SARS-CoV outbreak in 2003, a large number of health workers were infected by the virus after inadequate use of PPE or improper donning of PPE was reported. ${ }^{19,22,30}$

Although airborne transmission of SARS-CoV-2 has not been adequately proven, the $\mathrm{WHO}$ has recommended healthcare workers who perform aerosol-generating procedures on COVID-19 patients to use appropriate PPE to prevent airborne transmission including gloves, long-sleeved gowns, eye protection and fit-tested particulate respirators (N95 or equivalent, or higher level of protection). ${ }^{27}$ Some examples of aerosolgenerating medical procedures that were cited included tracheal intubation, non-invasive ventilation, tracheotomy, cardiopulmonary resuscitation, manual ventilation before intubation and bronchoscopy. Dental procedures were not mentioned in this guideline. However, it can be extrapolated that under the WHO guideline, dental practitioners should adhere to increased infection control measures when treating COVID-19 cases. It is also crucial that PPE is properly removed and disposed of to prevent cross-contamination after procedures.

\section{Surgical Masks vs Fit-Tested Particulate Respirators}

Surgical masks are effective against droplet transmission and confer some protection against contact transmission by limiting interaction between the hands and face. ${ }^{22}$ Thus, they are part of the standard PPE worn routinely in dentistry where highly transmissible infectious diseases are not commonly encountered. ${ }^{19}$ However, surgical masks are considered ineffective against airborne transmission. ${ }^{22}$ Instead, fit-tested particulate respirators such as the N95 mask or its equivalent should be used. ${ }^{31,32}$ Currently, the WHO has recommended routine use of fit-tested particulate respirators when performing aerosolgenerating procedures on COVID-19 patients. ${ }^{27}$

The efficacy of particulate respirators is contingent on a good seal between the respirator and the face. Consequently, particulate respirators should be fitted properly and staff must be trained to don them correctly. ${ }^{24}$ Particulate respirators have 2 drawbacks: the need for fit-testing and discomfort during usage.
Fit-testing is a laborious task and comprises a qualitative or quantitative fit test. ${ }^{33}$ Furthermore, not every individual can be fitted with a particulate respirator. Prolonged usage of respirators is also uncomfortable due to difficulty in breathing and tightness of fit. ${ }^{19,34,35}$

Several studies have compared the efficacy of surgical masks and particulate respirators to prevent infection by viral pathogens such as influenza and SARS-CoV. While most studies did not find a clear benefit for either surgical masks or particulate respirators against such infections, ${ }^{34-7}$ they also did not specifically study the risks of aerosol-generating procedures. Indeed, Loeb et al cautioned that the results of their study should not be generalised to aerosol-generating procedures where use of an N95 respirator would be prudent. ${ }^{38}$

Understandably, as COVID-19 is an emerging disease, there is a paucity of scientific evidence to support the efficacy of either surgical masks or particulate respirators in healthcare services. In a recent case report, 41 medical staff who treated a patient that was later found to be positive for COVID-19 did not contract the infection. ${ }^{39}$ This was despite the fact that aerosol-generating procedures were performed and only $15 \%$ of the staff were wearing N95 respirators while $85 \%$ of them wore surgical masks. The authors suggested that with surgical masks and proper precautions such as hand hygiene, the risk of infection by COVID-19 might not be significantly higher as compared to wearing an N95 respirator. Dental practitioners should also be reminded that surgical masks and respirator use, although critical, are part of a series of critical infection control measures. ${ }^{40}$

\section{Hand Hygiene}

Contact route is the most common mode of nosocomial infection in health services and contaminated hands are considered a significant culprit. ${ }^{24,41}$ Hand hygiene is a proven effective and critical measure to reduce the risk of transmission of any infectious agents in the healthcare sector. ${ }^{42,43}$ Notably, it was postulated as the single most important measure that prevented the spread of SARS-CoV in 2003. ${ }^{19}$

The WHO has recommended health workers to practise 5 moments of hand hygiene by cleaning their hands: 1) before touching a patient; 2) before clean/ aseptic procedures; 3) after body fluid exposure/risk; 4) after touching a patient; and 5) after touching patient surroundings. ${ }^{44,45}$ Additionally, the WHO encouraged health workers to practise hand hygiene before food 
preparation and eating and after using the restroom to prevent COVID-19 transmission. ${ }^{46}$

\section{Procedural Controls}

\section{Preprocedural Mouthwash}

A preprocedural mouthwash can reduce the number of viable bacteria in aerosols that are generated from dental procedures, and the same effect is thought to reduce viral load. ${ }^{25}$ The commonly used chlorhexidine mouthwash is bactericidal, but it appears to be ineffective against viruses. ${ }^{16,47}$ Since SARS-CoV-2 is vulnerable to oxidation, other solutions that contained oxidative agents such as hydrogen peroxide or povidone-iodine were suggested to be used instead. ${ }^{47}$

The efficacy of povidone-iodine mouthwash against respiratory tract viruses-including SARS-CoV and Middle East respiratory syndrome coronavirus (MERS$\mathrm{CoV}$ ) - has been studied. ${ }^{47,48}$ The in vitro study by Eggers et $\mathrm{al}^{48}$ found that the use of $0.23 \%$ povidone-iodine mouthwash for 15 seconds was sufficient to inactivate SARS-CoV, MERS-CoV, H1N1 and rotavirus. Therefore, $0.23 \%$ povidone-iodine preprocedural mouthwash is recommended to be used during the COVID-19 pandemic. It is especially useful in treatment when a rubber dam cannot be used to reduce the amount of aerosols. ${ }^{10,19}$

\section{Dry Field Technique}

During aerosol-generating dental procedures, rubber dam usage can significantly reduce the amount of aerosol and splatter around a 3-foot diameter of the operational field by up to $70 \%{ }^{49}$ However, the use of rubber dam is not possible in certain procedures such as scaling and polishing. ${ }^{16}$ It is important to note that even with rubber dam isolation, dental practitioners should also use a high-volume excavator to reduce further the amount of aerosols generated. ${ }^{10}$

\section{High-Volume Excavator}

High-volume excavators can reduce contamination from the operative site by $>90 \% 0^{3,12,50}$ For the suction system to be classified as a high-volume excavator, it must be capable of excavating a large volume of air within a short period. The high-volume excavator typically used in dentistry has a large opening (usually $\geq 8 \mathrm{~mm}$ ) and is attached to a system that will remove up to approximately $2.8 \mathrm{~m}^{3}$ of air in 1 minute. ${ }^{16}$

\section{Environmental Control}

In the treatment of COVID-19 patients, the WHO has recommended that they are treated in a room with adequate ventilation. An example is a negative pressure room that has a minimum of 12 air changes in 1 hour or at least $160 \mathrm{~L} / \mathrm{s} /$ patient in facilities that have natural ventilation. ${ }^{27}$ Access to the room should be limited to only essential personnel.

\section{Postprocedural Equipment and Surface Decontamination}

In their study, Ong et al found that surface decontamination is effective in removing traces of SARS-CoV-2 from an isolation room that housed COVID-19 cases. $^{9}$ As the virus can remain viable on instruments and surfaces for a period of time, it is important to perform thorough instrument and surface decontamination to prevent nosocomial transmission.

The US Environmental Protection Agency has published a list of suitable disinfectants for surface decontamination against SARS-CoV-2. ${ }^{51}$ The list includes sodium hypochlorite and alcohol solutions that are readily available in dental clinics. Apart from the dental chair, common areas and appliances that are used within the operatory such as door handles, chairs and desks - should also be cleaned regularly. ${ }^{10}$

\section{Biohazard Waste Management}

SARS-CoV-2 waste is a biohazard since it can be infectious. Staff who are involved in transporting such waste must be aware of the possible health and safety hazards posed when doing so. ${ }^{52,53}$ Therefore, they must be given proper training on appropriate handling and disposal methods.

\section{Dental Practice Management Measures}

Dental practice management measures may need to be implemented to reduce the risk of COVID-19 transmission in staff and patients. Staff must be trained on proper donning and doffing of PPE and fit-testing of particulate respirators should be done on them. Special consideration should be made to redeploy staff who are older, immunocompromised or have existing comorbidities to work in positions that requires less patient contact. ${ }^{28}$ Dental clinic managers can also establish a staff health surveillance system to monitor and manage staff who fall ill. ${ }^{54}$ The number of individuals in the clinic should be reduced, including limiting the number of those who accompany a patient to just 1. Similar measures have also been put in place in Malaysia. ${ }^{10}$

At the peak of the COVID-19 outbreak in Mainland China, dental practice management measures included postponement of all elective dental procedures until 
the outbreak is contained and only urgent or emergency treatments were allowed. ${ }^{18}$ Similar measures were announced by the American Dental Association on 1 April 2020;5 in Singapore, they were implemented on 7 April 2020..$^{56,57}$ In Singapore, urgent dental treatment refers to management of conditions that require immediate attention to relieve severe pain and/or risk of infection. On the other hand, emergency dental treatment refers to management of conditions that are potentially life-threatening and require immediate treatment to stop ongoing tissue bleeding, alleviate severe pain or infection. Dental practitioners should keep themselves abreast of the latest guidelines published by both national and international authorities and adhere strictly to them.

\section{Business Continuity Plans}

Business continuity plans should be implemented to minimise disruption to dental clinic services. A team-based practice that segregates staff into teams to minimise contact with each other will help prevent COVID-19 transmission in dental practice. Staff can undergo cross-training in order to ensure that essential tasks can still be performed. The establishment of a reliable channel of communication amongst the staff can also facilitate timely updates and sharing of information..$^{54}$

\section{Limitation}

The main limitation of this review was the paucity of evidence on COVID-19. An attempt was made to include the latest information on COVID-19 as much as possible, but references to studies on SARS-CoV and influenza outbreaks had to be made. Research is ongoing and new information will be published in the future. As such, best practices and recommendations for dental practitioners during the COVID-19 pandemic may change.

\section{Conclusion}

A comprehensive review of the current literature on precautions when providing dental care during the COVID-19 pandemic was discussed and recommendations for dental practitioners were made. Dental practitioners need to stay abreast of the latest guidelines that are released by local and international authorities and comply with them.

\footnotetext{
Acknowledgement

The authors thank Safiyya Mohamed Ali for her assistance with editing this manuscript.
}

\section{REFERENCES}

1. World Health Organization. WHO timeline-COVID-19, 27 April 2020. Available at: https://www.who.int/news-room/detail/27-04-2020who-timeline---covid-19. Accessed on 18 May 2020.

2. World Health Organization. Modes of transmission of virus causing COVID-19: implications for IPC precaution recommendations, 29 March 2020. Available at: https://www.who.int/publications-detail/ modes-of-transmission-of-virus-causing-covid-19-implications-foripc-precaution-recommendations. Accessed on 18 May 2020.

3. Micik RE, Miller RL, Mazzarella MA, Ryge G. Studies on dental aerobiology. I. Bacterial aerosols generated during dental procedures. J Dent Res 1969;48:49-56.

4. World Health Organization. Q\&A on coronaviruses, 17 April 2020. Available at: https:/www.who.int/news-room/q-a-detail/q-acoronaviruses. Accessed on 18 May 2020.

5. World Health Organization. Report of the WHO-China Joint Mission on Coronavirus Disease 2019 (COVID-19), 28 February 2020. Available at: https://www.who.int/publications-detail/report-of-thewho-china-joint-mission-on-coronavirus-disease-2019-(covid-19). Accessed on 18 May 2020.

6. To KKW, Tsang OTY, Yip CCY, Chan KH, Wu TC, Chan JMC, et al. Consistent detection of 2019 novel coronavirus in saliva. Clin Infect Dis 2020; doi:10.1093/cid/ciaa149.

7. World Health Organization. Infection prevention and control during health care when novel coronavirus (nCoV) infection is suspected, 19 March 2020. Available at: https://www.who.int/publications-detail/ infection-prevention-and-control-during-health-care-when-novelcoronavirus-(ncov)-infection-is-suspected-20200125. Accessed on 18 May 2020.

8. Monaghan NP. Emerging infections-implications for dental care. Br Dent J 2016;221:13-5.

9. Ong SWX, Tan YK, Chia PY, Lee TH, Ng OT, Wong MSY, et al. Air, surface environmental, and personal protective equipment contamination by severe acute respiratory syndrome coronavirus 2 (SARS-CoV-2) from a symptomatic patient. JAMA 2020; 323:1610-2

10. Malaysian Dental Council. Guidelines for handling issues related to spreading COVID-19 pandemic in dental health services. Available at: http://mdc.moh.gov.my/uploads/covid19.pdf. Accessed on 18 May 2020.

11. Van Doremalen N, Bushmaker T, Morris DH, Holbrook MG, Gamble A, Williamson BN, et al. Aerosol and surface stability of SARS-CoV-2 as compared with SARS-CoV-1. N Engl J Med 2020;382:1564-7.

12. Bentley CD, Burkhart NW, Crawford JJ. Evaluating spatter and aerosol contamination during dental procedures. J Am Dent Assoc 1994;125:579-84

13. Miller RL, Micik RE, Abel C, Ryge G. Studies on dental aerobiology. II: Microbial splatter discharged from the oral cavity of dental patients. J Dent Res 1971;50:621-5.

14. Chen N, Zhou M, Dong X, Qu J, Gong F, Han Y, et al. Epidemiological and clinical characteristics of 99 cases of 2019 novel coronavirus pneumonia in Wuhan, China: a descriptive study. Lancet 2020; 395:507-13.

15. Hinds WC. Properties, Behaviour, and Measurement of Airborne Particles. New York: Wiley; 1982. p. 6-8.

16. Harrel SK, Molinari J. Aerosols and splatter in dentistry: a brief review of the literature and infection control implications. J Am Dent Assoc 2004;135:429-37.

17. Cottone JA, Terezhalmy GT, Molinari J. Practical Infection Control in Dentistry. Baltimore: Williams \& Wilkins; 1996. p. 139-40. 
18. Meng L, Hua F, Bian Z. Coronavirus disease 2019 (COVID-19): emerging and future challenges for dental and oral medicine. J Dent Res 2020;99:481-7.

19. Samaranayake LP, Peiris M. Severe acute respiratory syndrome and dentistry: a retrospective review. J Am Dent Assoc 2004; 135:1292-302.

20. Pung R, Chiew CJ, Young BE, Chin S, Chen MI, Clapham HE, et al. Investigation of three clusters of COVID-19 in Singapore: implications for surveillance and response measures. Lancet 2020;395:1039-46.

21. Lauer SA, Grantz KH, Bi Q, Jones FK, Zheng Q, Meredith HR, et al. The incubation period of coronavirus disease 2019 (COVID-19) from publicly reported confirmed cases: estimation and application. Annals of Int Med 2020;172:577-82.

22. Harte JA. Standard and transmission-based precautions: an update for dentistry. J Am Dent Assoc 2010;141:572-81.

23. Kohn WG, Collins AS, Cleveland JL, Harte JA, Eklund KJ, Malvitz DM. Guidelines for infection control in dental health-care settings-2003. MMWR Recomm Rep 2003;52:1-61.

24. Siegel JD, Rhinehart E, Jackson M, Chiarello L. 2007 Guideline for Isolation Precautions: Preventing Transmission of Infectious Agents in Healthcare Settings, July 2019. Available at: https://www.cdc.gov/ infectioncontrol/pdf/guidelines/isolation-guidelines-H.pdf. Accessed on 18 May 2020.

25. Marui VC, Souto MLS, Rovai ES, Romito GA, Chambrone L, Pannuti CM. Efficacy of preprocedural mouthrinses in the reduction of microorganisms in aerosol: a systematic review. J Am Dent Assoc 2019;150:1015-26.

26. Samaranayake LP, Scheutz F, Cottone JA. Infection Control for the Dental Team. Copenhagen, Denmark: Munksgaard; 1991.

27. World Health Organization. Advice on the use of masks in the context of COVID-19, 6 April 2020. Available at: https://www who. $\mathrm{int} /$ publications-detail/advice-on-the-use-of-masks-in-the-communityduring-home-care-and-in-healthcare-settings-in-the-context-of-thenovel-coronavirus-(2019-ncov)-outbreak. Accessed on 18 May 2020.

28. Grant M, Schramm A, Strong B, Buchbinder D, Ellis E, Wolvius E, et al. AO CMF International Task Force Recommendations on Best Practices for Maxillofacial Procedures during COVID-19 Pandemic, 22 April 2020. Available at: https://aocmf3.aofoundation.org/-/media/ project/aocmf/aocmf/files/covid-19/ao_cmf_covid-19 task_force guidelines.pdf?la $=$ en\&hash $=$ C2B89E1E6E9AB72EBF386C747D3B C74CF1009C1E. Accessed on 18 May 2020.

29. European Centre for Disease Prevention and Control. Personal protective equipment (PPE) needs in healthcare settings for the care of patients with suspected or confirmed novel coronavirus (2019-nCoV), February 2020. Available at: https://www.ecdc.europa.eu/sites/default/ files/documents/novel-coronavirus-personal-protective-equipmentneeds-healthcare-settings.pdf. Accessed on 18 May 2020.

30. Low JGH, Wilder-Smith A. Infectious respiratory illnesses and their impact on healthcare workers: a review. Ann Acad Med Singapore 2005;34:105-10.

31. Gawn J, Clayton M, Makison C, Crook B. Evaluating the protection afforded by surgical masks against influenza bioaerosols: gross protection of surgical masks compared to filtering facepiece respirators. Health and Safety Executive, 2008. Available at: https:// www.hse.gov.uk/research/rrpdf/rr619.pdf. Accessed on 18 May 2020.

32. Booth CM, Clayton M, Crook B, Gawn JM. Effectiveness of surgical masks against influenza bioaerosols. J Hosp Infect 2013;84:22-6.

33. Bunyan D, Ritchie L, Jenkins D, Coia JE. Respiratory and facial protection: a critical review of recent literature. J Hosp Infect 2013;85:165-9.
34. Offeddu V, Yung CF, Low MSF, Tam CC. Effectiveness of masks and respirators against respiratory infections in healthcare workers: a systematic review and meta-analysis. Clin Infect Dis 2017;65:1934-42.

35. Baig AS, Knapp C, Eagan AE, Radonovich Jr LJ. Health care workers' views about respirator use and features that should be included in the next generation of respirators. Am J Infect Control 2010;38:18-25.

36. MacIntyre CR, Wang Q, Cauchemez S, Seale H, Dwyer DE, Yang $\mathrm{P}$, et al. A cluster randomized clinical trial comparing fit-tested and non-fit-tested N95 respirators to medical masks to prevent respiratory virus infection in health care workers. Influenza Other Respir Viruses 2011;5:170-9

37. Radonovich Jr LJ, Simberkoff MS, Bessesen MT, Brown AC, Cummings DAT, Gaydos CA, et al. N95 respirators vs medical masks for preventing influenza among health care personnel: a randomized clinical trial. JAMA 2019;322:824-33.

38. Loeb M, Dafoe N, Mahony J, John M, Sarabia A, Glavin V, et al. Surgical mask vs N95 respirator for preventing influenza among health care workers: a randomized trial. JAMA 2009;302:1865-71.

39. Ng K, Poon BH, Puar THK, Quah JLS, Loh WJ, Wong YJ, et al. COVID-19 and the risk to health care workers: a case report. Ann Intern Med 2020;doi: 10.7326/L20-0175.

40. Bin-Reza F, Chavarrias VL, Nicoll A, Chamberland ME. The use of masks and respirators to prevent transmission of influenza: a systematic review of the scientific evidence. Influenza Other Respir Viruses 2012;6:257-67.

41. Boyce JM, Pittet D. Guideline for hand hygiene in health-care settings. Recommendations of the Healthcare Infection Control Practices Advisory Committee and the HICPAC/SHEA/APIC/IDSA Hand Hygiene Task Force. MMWR Recomm Rep 2002;51:1-45.

42. Larson EL, Early E, Cloonan P, Sugrue S, Parides M. An organizational climate intervention associated with increased handwashing and decreased nosocomial infections. Behav Med 2000;26:14-22.

43. Fox MK, Langner SB, Wells RW. How good are hand washing practices? Am J Nurs 1974;74:1676-8.

44. World Health Organization. WHO Guidelines on Hand Hygiene in Health Care. Geneva, Switzerland: WHO Press; 2009.

45. Sax H, Allegranzi B, Uçkay I, Larson E, Boyce J, Pittet D. 'My five moments for hand hygiene': a user-centred design approach to understand, train, monitor and report hand hygiene. J Hosp Infect 2007;67:9-21

46. World Health Organization. Interim recommendations on obligatory hand hygiene against transmission of COVID-19, 1 April 2020. Available at: https://www.who.int/who-documents-detail/ interim-recommendations-on-obligatory-hand-hygiene-againsttransmission-of-covid-19. Accessed on 18 May 2020.

47. Peng X, Xu X, Li Y, Cheng L, Zhou X, Ren B. Transmission routes of 2019-nCoV and controls in dental practice. Int J Oral Sci $2020 ; 12: 9$

48. Eggers M, Koburger-Janssen T, Eickmann M, Zorn J. In vitro bactericidal and virucidal efficacy of povidone-iodine gargle/ mouthwash against respiratory and oral tract pathogens. Infect Dis Ther 2018;7:249-59.

49. Samaranayake LP, Reid J, Evans D. The efficacy of rubber dam isolation in reducing atmospheric bacterial contamination. ASDC J Dent Child 1989;56:442-4.

50. Jacks ME. A laboratory comparison of evacuation devices on aerosol reduction. J Dent Hyg 2002;76:202-6.

51. United States Environmental Protection Agency. List N: Disinfectants for Use Against SARS-CoV-2, 7 May 2020. Available at: https://www. epa.gov/pesticide-registration/list-n-disinfectants-use-against-sarscov-2. Accessed on 18 May 2020. 
52. Ministry of Health Singapore. MOH Pandemic Readiness and Response Plan for Influenza and Other Acute Respiratory Diseases, April 2014. Available at: https://www.moh.gov.sg/docs/ librariesprovider5/diseases-updates/interim-pandemic-plan-publicver-_april-2014.pdf. Accessed on 18 May 2020.

53. National Environment Agency, Singapore. Interim Guidelines for Environmental Cleaning and Disinfection of Areas Exposed to Confirmed Case(s) of COVID-19 in Non-Healthcare Premises, 6 May 2020. Available at: https://www.nea.gov.sg/our-services/ public-cleanliness/environmental-cleaning-guidelines/guidelines/ guidelines-for-environmental-cleaning-and-disinfection. Accessed on 18 May 2020.

54. Enterprise Singapore. Guide on Business Continuity Planning for COVID-19, 3rd edition, 1 April 2020. Available at: https://www. enterprisesg.gov.sg/-/media/esg/files/covid-19/guide-on-businesscontinuity-planning-for-covid-edition-3-15-april-2020final.pdf?la=en. Accessed on 18 May 2020.
55. American Dental Association. ADA Urges Dentists to Heed April 30 Interim Postponement Recommendation, Maintain Focus on Urgent and Emergency Dental Care Only, 1 April 2020. Available at: https://www.ada.org/en/press-room/news-releases/2020-archives/ april/summary-of-ada-guidance-during-the-covid-19-crisis?utm source $=$ adaorg\&utm_medium $=$ adahomealert\&utm_content $=\mathrm{cv}$ pm-ebd-interim-response\&utm_campaign $=$ covid-19. Accessed on 18 May 2020.

56. Ministry of Health Singapore. Continuation of essential healthcare services during period of heightened safe distancing measures, 4 April 2020. Available at: https://www.moh.gov.sg/news-highlights/ details/continuation-of-essential-healthcare-services-during-periodof-heightened-safe-distancing-measures. Accessed on 18 May 2020.

57. Government of Singapore. COVID-19 circuit breaker: heightened safe-distancing measures to reduce movement, 3 April 2020. Available at: https://www.gov.sg/article/covid-19-circuit-breaker-heightenedsafe-distancing-measures-to-reduce-movement. Accessed on 18 May 2020 